\title{
A TERÜLETFEJLESZTÉS FINANSZÍROZÁSI RENDSZERE AZ EU CSATLAKOZÁS TÜKRÉBEN
}

\section{(Towards a New System of Regional Development Finance: Adaptation to the EU Standards)}

\section{RUTTKAY ÉVA}

Bevezetés: az Európai Unióhoz való csatlakozás - kihivás és lehetőség a modernizációra

A modern piacgazdasági állami támogatáspolitika és finanszírozási rendszerre való áttérés a magyar gazdasági modernizáció egyik további megteendő lépése. $\mathrm{Az}$ Európai Unióhoz való csatlakozás egyik modernizációs hozadéka - az uniós támogatás politikai eszközökhöz való hozzájutáson túl - is éppen az e téren való előrelépés lenne. Nem szabad ugyanakkor elfelejteni, hogy ez egy alapvetően szocialista - szociáldemokrata értékrenden és filozófián alapuló technika és eljárás rend meghonosítását jelenti.

A tagságra való felkészủlés a társadalmi, gazdasági kohézió témaköre esetében az alábbi fö témaköröket foglalja magába:

- A gazdaságpolitikai beágyazódás megteremtésének kérdései, ezen belül:

- makropálya, abszorpciós képesség,

- különféle állami-nemzeti szektorpolitikák, valamint ehhez kapcsolódóan az egész támogatás politikai rendszer felülvizsgálata a csatlakozás szempontjából, (célrendszer, eljárások),

- a decentralizált finanszírozási modell kialakítása.

- Új típusú, középtávú tervezési rendszer kialakítása (programozás):

- a programozási eljárás hazai gyakorlatba való ültetése,

- szükséges múködtető rendszer kialakitása,

- államháztartási rendszerbe való beágyazás.

- Területszervezési kérdések, a régió problémakör;

- A fentiekhez kapcsolódó intézmény-kialakítás:

- a szükséges gazdaságirányítási-igazgatási feltételek megteremtése,

- közigazgatási szervezési feladatok,

- régiószervezési kérdések,

- központi közigazgatáson belüli szervezeti kérdések. 


\section{A gazdaságpolitikába történő illesztés}

Vitathatatlan, hogy a csatlakozással (sőt már az előkészulletek kapcsán is) a gazdaságpolitikán belül is hangsúlyeltolódások mennek végbe. A felértékelỏdő strukturális politikára kettős követelmény hárul.

- Egyrészt a már elindult - a gazdaság export- és versenyképességét tartósan no̊velő - szerkezeti változásokat eredményezó folyamatokat kell felerősitenie.

- Másrészt a sokrétü szerkezeti differenciálódási folyamatot megfelelő kiegyenlítő mechanizmusokkal szükséges fékeznie.

A gazdaság makroszintü szabályozása és a struktúrapolitika összhangja - még az EU tagországok esetében is - alapvetően nemzeti hatáskörben érvényesül.

A csatlakozás várható hatásai a makrogazdasági egyensúlyra és a költségvetés helyzetére

Az EU közös költségvetéséhez való magyar hozzájárulás lehetőségét a költségvetés bevételi struktúrájának és nagyságrendjének "csatlakozásfüggő" változása befolyásolja. A magyar költségvetés kiadási oldalát terhelik az EU költségvetésbe történö befizetésen kívül a csatlakozás megvalósításához szükséges intézményi, vámügyi határellenörzési, rendórségi fejlesztések, a tervezés, végrehajtás, ellenőrzés EU-konform átalakításának adminisztratív költségei, valamint az információs rendszerek kiépítéséhez szuikséges ráfordítások, viszont csökkentheti az agrártámogatásokhoz bevonható $\mathrm{EU}$ forrás. A bevételeket részben növelheti az a hatás, amit az 1996. évet követỏen bizonyos adómentességek, kedvezmények fokozatos megszuintetése (pl. külföldiek befektetési adókedvezménye) eredményez, viszont csökkenti az EU közös költségvetésébe befizetendő vámtételek kiesése a bevételek kőzủl. A csatlakozással megvalósuló közős kưlsỏ vám- és a belsó vámok megszủntetése jelentősen megváltoztatja a vám és importilleték-befizetések nagyságrendjének alakulását.

Portugália, Spanyolország, Görögország csatlakozási tapasztalatai azt mutatják, hogy kiélezett versenyhelyzetben - legalábbis rövid távon - romlik a kulkereskedelmi egyenleg és a folyó fizetési mérleg. Ez még inkább aláhúzza annak jelentőségét, hogy már a felkészülés időszakában is, majd a csatlakozást követően a társfinanszírozás révén törekedni kell a versenyképességünk növelését biztosító strukturális célú támogatások fokozott igénybevételére.

Belépéskor még egy összességében pozitív EU-szaldó ellenére is nöhet az államháztartás deficitje, tekintettel arra, hogy az EU által nyújtott addicionális források elsődlegesen a programok finanszírozását és nem a költségvetési bevételek közvetlen növelését szolgálják. Az államháztartási terhek csökkentésére, a költségvetésre ható tényezỏk pontosítása, számszerüsítése után, a csatlakozási tárgyalások keretei között lehet majd módot találni.

$\mathrm{Az}$ államháztartási reform kővetkezetes végrehajtása során a társfinanszírozásra átcsoportosítható hazai források növelésével azonban az EU források nagymértékben bővítenék a kőltségvetés mozgásterét is, elősegítve a gazdaság modernizációját és dinamizálását. Olyan fejlesztéseket indíthatnának el, amelyek multiplikátor hatása már rövidtávon is érzékelhetővé válna (pl. az infrastruktúra- 
fejlesztéseknél, a foglalkoztatásban, adófizetésben, a pénzügyi transzferekhez kötődő termelésben, stb.), hosszabb távon pedig az oktatásban, képzettségi szintben, illetve hazánk összeurópai kereskedelmi- és tőkekapcsolatokba való beintegrálódásában.

Nyilvánvaló, hogy a költségvetéssel kapcsolatos kötelezettségek kérdése, konkrét számai nagyrészt bizonytalanok és viszonylagosak e stádiumban. A csatlakozás költségvetési terhei olyan stratégiai fontosságú kérdés, amit csak egy tágabb összefüggésrendszerbe ágyazottan - pl. egy konvergencia-program makro-hatásait figyelembe véve - szabad vizsgálni.

A hazai befizetések nagysága a jelen stádiumban még tisztázatlan, azonban abból a feltételezésből lehet kiindulni, hogy a bruttó hazai termék után számolt 1,27\%-os felsö határt nem haladhatja meg.

$\mathrm{Az}$ ország vélemény szerint az agrár költségvetést $\mathrm{kb}$. 1 Mrd ECU-vel, a strukturális alapokat (a 4\%-os plafon miatt) $\mathrm{kb}$. 1,4 Mrd ECU-vel, a belsỏ piaci mechanizmusokat néhány százmillió ECU-vel terhelnénk, így várhatóan 2,5-3,1 Mrd ECU lesz a bruttó transzfer. Mindez azt jelenti, hogy belépésünk első éveiben (2006-ig) a nettó transzfer évi 2,0-2,5 Mrd ECU körül lenne. Ez böven kompenzálná a belépés utáni első években várható fizetési mérlegromlást.

$\mathrm{Az}$ eddig csatlakozott országok tapasztalatai szerint minden taggá váló ország számára lehetővé vált az átmeneti felmentés, derogáció alkalmazása a szabályozások átvételében. Az első kibővülés alkalmával az átmeneti időszak (az integrációs szervezeten belüli felzárkózás) jellemző idötartama 5 év volt a közösségi költségvetéshez való teljes mértékü hozzájárulás elérése terén. Amennyiben a "felvételiző" új tag fejlettségi szintje nem éri el a közösségi átlagot, a technikai adaptáció, az időleges eltérés és az átmeneti rendelkezések intézményei segítik a felzárkózásban.

\section{Abszorpciós kapacitás}

Az EU-tól megszerezhetö támogatások mértéke egyrészt a gazdaság teljesítỏképességének alakulásától, másrészt a gazdaság felszivó képességének, abszorpciós kapacitásának alakulásától függ.

A gazdasági teljesitöképesség megitélése a hosszú távú és középtávú növekedési pálya, ezen belül a felhalmozási-beruházási kiadások alakulásának függvénye. $\mathrm{A}$ PM középtávú előrejelzése adja meg a számítások alapját, amely az alapot jelenti a magyar gazdaság pályájának az előrejelzésében. A PM a 2000. éven túlnyúló számításaiban fokozatosan gyorsuló GDP-növekedést prognosztizál, az ezredvéghez közeledve új, magas növekedési rátát ér el. Növekszik a beruházási hányad, mind a magánszférában, mind a közösségi beruházások esetében. 2000-ben a beruházások aránya a GDP százalékában összességében eléri a $29 \%$-ot, s ezen belül az állami beruházásoké kb. $4 \%$-ot $(480 \mathrm{Mrd} \mathrm{Ft})$.

A különböző szakértői csoportok számitásait figyelembe véve a gazdasági pálya alakulása egészében véve kedvező képet sugall az EU támogatási rendszeréhez való illeszkedéshez. 
- A gazdaság abszorpciós képességének alakulása makro- és mikrokörnyezeti szinten, amely különféle megközelítések, számítások alapján becsülhetö.

- Makroszinten az egész nemzetgazdaság fogadókészsége értendő. Ezen belül is a közpénzek még további bontásban a felhalmozásra szánható eszközök nagyságát, egész pontosan az EU által társ-finanszírozható források alakulását kell számításba venni.

A gazdaság mikroszférájának, fogadókészségének a megbecsülése is elsősorban a társ-finanszírozásba fogható pénzeszközök megbecslését jelenti, amely már több bizonytalansági tényezöt rejt magában. Az abszorpciós képesség magába foglalja egyébként az emberi-vállalkozási képességeket is. Képesek lesznek-e magyar vállalkozások, önkormányzatok vagy közösségi szféra a megfelelö curópai gondolkodásmódot, a csatlakozó kultúrát (projekt és programkészités, pályázatok készítési technikája) átvenni.

Az abszorpciós képesség közgazdasági értelemben tágabban is értelmezhetö, nem csak a strukturális alapok fogadókészségéhez viszonyítva. Tágabb értelemben az ország abszorpciós képességénél az alábbiakat kell még figyelembe venni.

Szakértöi vélemények szerint a magyar gazdaság kifejezetten magas tökeabszorpciós képességgel rendelkezik, mivel:

- A magyar gazdaság szinkronban van a világgazdaság tőkefolyamataival, amelyekben a külföldi müködötöke beruházások a világgazdaság meghatározó folyamatává váltak. A privatizáció után a zöldmezös ipari befektetések szerepe tovább nött, s ma már Magyarország és a régió esetében a külföldi, zöldmezős ipari beruházások adják a GDP növekedés dinamikáját. A magyar tőkeabszorpciós képesség a privatizáció után a fejlett feldolgozó ipari termékcsoportokban a legerösebb. A zöldmezös külfôldi beruházások a világ legnagyobb beruházóitól érkeznek, amelyek folyamatosan bővítik tőkekivitelüket, ez valószinüsíti a hazai gazdasági trend kedvezö alakulását. A zöldmezös ipari beruházások viszonylag kevés új munkahelyet teremtenek, tehát munkaerő oldalról nincs korlátja a tökeabszorpciós képességnek. A külföldi tőkebefektetések motivációi sokrétúek Magyarország esetében, ami jelentős tőkeabszorpciós képességre utal.

- A külföldi tőkebefektetések nyomán a magyar gazdaságban jelentős a külföldi kontroll, ami további beruházásokra motiválja a külföldi tulajdonosokat. A privatizált cégekben is fejlesztenek. A várható zöldmezös beruházások 1998-2004 között évi 1-1,5 Mrd USD közé tehetők.

- A regionális fejlödési szerkezet alakulása is a magas tökeabszorpciós képességet támasztja alá. Az ipari zöldmezös beruházások jelentös földrajzi koncentrációt mutatnak.

- A magyar gazdaság magas tőkeabszorpciós képességét a meglévő szük infrastrukturális keresztmetszetek is fenntartják.

- A GDP, a nemzeti vagyon, a szellemi tőke közötti új arányok folyamatosan magasan tartják egy, a világgazdaságba integrálódó ország tökeabszorpciós képességét. A magyar gazdaságban beruházási hiány alakult ki, ami az EU integráció során folyamatosan magasan tartja a tőkeabszorpciós képességet.

- A gazdasági növekedés automatikusan erösíti a gazdaság tökeabszorpciós képességét. 
Végül a fentiek alapján kimutatható, hogy megvan a "saját erō", mivel kialakult egy tökeerös hazai tulajdonos osztály, amelyik ugrásra készen várja a kedvező beruházási klímát. A jelenlegi kormányzati programok ugyan széttagoltan, de lényegében a szükséges "saját erő" forrását kontroll és koordináció nélkül ma is beteszik a magyar gazdaságba. Továbbá a "saját eró" a külfóldi múkődótőke befektetésekhez kapcsolódó forrásokból is táplálkozik.

A kőltségvetési közvetlen hatásokon túlmenben az EU támogatásoknak a nemzetgazdaság egésze szempontjából is lesznek elönyei, bár ezek nehezen számszerüsíthetơk, illetve jelezhetök elöre. A megkapható támogatásokon túlmenően már az EU kővetelményeknek a támogatási rendszerben, illetve politikában való érvényesítésétól önmagában is pozitív hatások várhatók a csatlakozásig hátralevő időben.

Meg kell említeni, hogy szükebben a strukturális alapok tekintetében vannak olyan szakértöi vélemények, melyek szerint a magyar gazdaság jelenlegi (nem potenciális) tőkeabszorpciós képessége erősen a határán mozog a potenciális fogadókészségnek. Ennek fö okait a kővetkezőkben látják:

- A gazdasági növekedés elmarad attól az 5-7\%-os sávtól, amely már automatikusan és érezhetỏen, ráadásul folyamatosan javítja a tőkevonzást és a tőkefelszivást.

- A kis belső piac határokat szab a tökeabszorpciónak, ezt csak a Kárpátmedence régió integrációjával lehet feloldani, az ezt megvalósítani képes politikai és gazdasági folyamatok ma lassúak (egyes esetekben ellentétesek a vázolt iránnyal).

- A dinamikus területek és ágazatok és a lemaradó területek és ágazatok kőzött nagyon gyengék a kapcsolatok, az elsỏ nem képes dinamizálni a másodikat.

- A fizikai és humán infrastruktúra korlátok igen erősen érzékelhetök.

- Az 1990-97 kőzőtt lezajlott privatizáció és piaci átmenet a belfơldi piac jelentős részét (mintegy 60-70\%-át) átadta külföldi befektetőknek, ezért a belföldi piaci szereplőkơn keresztül történő dinamizálás lehetősége leszúkült.

- Nem érzékelhetó világos kormányzati stratégia a beruházások és a reálgazdaság bövítésére, sőt ezzel ellentétes a pénzügyi politika.

- Nem érzékelhető egy innováció-kőzpontú kormányzati politika.

- A vállalkozói struktúra erös szakadást mutat a foglalkoztatást legjobban megoldó kőzépvállalati csoportban, ami korlátozza a belföldi piac bóvullését.

- A kereskedelmi mérleg 3 milliárd dollár kơrùli passzivumra látszik beállni, amely mögött jelentős rejtett tóketranszfer húzódik meg ami egy elmaradt beruházási-növekedési forrást jelent.

\section{A tervezési rendszer kialakítása (Programozás)}

Az Európai Unióban a támogatási rendszerek elosztása meghatározott eljárási rend, az ún. programozási folyamat keretében történik. Ennek a korszerü és hatékony tervezési eljárásnak az átvétele az ország modernizációja szempontjából önmagában véve is igen fontos lépés, az ország az Unióhoz való csatalakozás kapcsán szükségképpen köteles is erre. 
A Strukturális és Kohéziós Alapokhoz való hozzájutás jogi feltételei között szerepel a tagállamok által készített nemzeti (vagy regionális) fejlesztési keretprogram kötelező tartalma és időhorizontja. Ez a hatéves költségvetési elkötelezettséggel járó, meghatározott felépítésủ és tartalmú középtávú programok kialakitását követeli meg, amelynek intézményi és metodikai kereteit meg kell teremteni. Az európai szabályozásban igen fontos követelmény, hogy a programoknak több évre szóló, kvantifikált, számon kérhető célokat kell kitüznie és ezekhez finanszirozási forrásokat biztosítani - a programokba foglalt és jóváhagyott összegekben. Így a hatékonysági ellenörzés is lehetővé válik.

A fentieknek megfelelően a program készités komplex követelmény rendszere alapvetően két terület reformjának követelményét foglalja magába:

- a programkészítés feladatait, a programozási folyamatot,

- a költségvetés középtávú tervezésének feladatait.

\section{Programkészités}

A Magyarországon ma még nem alkalmazott programozás tág értelemben magába foglalja a tervezést és a megvalósítást egyaránt. Szükebb értelemben egy olyan szigorú eljárási rend, amely meghatározó mind a programok kidolgozása, mind azok megvalósitása szempontjából.

A programozás lényege:

- stratégiai megközelítés: csak stratégiai programba illeszkedő projekt (operatív program) támogatható,

- integrált és nem centralizált forráselosztás: a különbözỏ források integrált felhasználásával, a szinergikus hatással növelni lehet a források felhasználásának a hatékonyságát,

- koherencia követelménye (célpiramis): az országos makro céloknak és a helyi szintủ fejlesztési szándékoknak egymást erősíteniük kell. Több, egymást erösitö és kiegészitő intézkedés támogatásával érhetö el a legkedvezőbb társadalmi-gazdasági hatás,

- épit a decentralizációból fakadó vertikális és horizontális koordinációra, együttmüködésre,

- integráló eleme a területiség, így a fejlesztési egységek, az akcióterületek a különböző (országos, regionális és kisebb) területegységek,

- alapkövetelmény a finanszírozás és megvalósitás folyamatának ellenőrizhetösége, átláthatósága, ami monitoring rendszer kiépítését igényli.

Az Unió országaiban sem egyforma a területfejlesztés, a területi tervezés gyakorlata, így a velünk szembeni elvárás sem egy nem létező egységes gyakorlathoz való igazodás, hanem azonos alapelvek érvényesítése, a szükséges közös elemek, kapcsolódási pontok beépitése a hazai gyakorlatba. Az EU ugyan nem fogalmaz meg direktívákat a területfejlesztéssel, a területei tervezéssel szemben, de a strukturális alapok igénybevételét feltételekhez köti, így ezeket saját érdekünkben alkalmazni kell. Várható, hogy a tervezéssel kapcsolatos közösségi elvárások is a strukturális alapok felhasználásának szabályozásába kerülnek be 1999-et követöen. 
A programozás bevezetésének már ma is létező alapjai, erősségei:

- a területfejlesztés jogi kereteinek megléte,

- a stratégiai programozás gerince a stratégiai tervezés, amelyhez a magyar gyakorlatban a fejlesztési koncepció készitése áll közel. A különbözö területegységekre készült, illetve készülö fejlesztési koncepciók kibövíthetők, átalakíthatók stratégiai programmá,

- a források egy részét már ma is decentralizálták, és pályázati úton használják fel,

- kialakult a pénzintézeti rendszer (kincstár, bankok), amely alkalmas a támogatások kezelésére.

A bevezetés elöfeltételeinek hiányosságai, gyengeségek:

- A programozás bevezetésének legfóbb akadálya a jelenlegi folyó költségvetési tervezési gyakorlat. Így a stratégiai és operatív programokból is hiányzik a reális költségvetési háttér.

- Nincs valós kapcsolat a stratégiai tervezés és az operatív (ágazati) programok között.

- A konkrét projektek monocentrikusak. Hiányos a más programokkal való harmonizálás. Kialakulatlan a széleskörü egyeztetési mechanizmus.

- Koordinálatlan a kủlönbőző (központi) források felhasználása. Az alsóbb szinteken hiányzik a fejlesztési szándékot erösítő saját forrás.

- A regionális szint gyengesége. Nincs önálló döntési hatásköre és finanszírozási forrása. Nem tisztázott a szint kompetenciája, a tervek tartalma.

- $\mathrm{Az}$ önkéntesen alakuló, számtalan szubjektív (politikai) elemet hordozó régiók nem szolgálják a hosszabb távú stratégiai programozást.

- Nincs területfejlesztési monitoring, hiányzik a támogatások felhasználásának értékelési mechanizmusa.

A programozási folyamat a gyakorlatban különböző - szektorális, horizontális és regionális - támogatási formákat, valamint egyes ágazati, illetve a hosszú távú területfejlesztési koncepción alapuló regionális fejlesztési terveket integrálja rendszerbe, támaszkodva a lokális, regionális szintủ - partnerségen alapuló szereplök közötti korporatív struktúrákra, a helyi köz- és magánforrások bevonására és a határ menti együttmüködés kiaknázására.

A programkészítés folyamata a hazai körülmények és a törvényi keretek figyelembevételével a következő séma szerint képzelhető el.

Alapelvként rögzíthető, hogy olyan rendszer kialakítása szükséges, ami biztosítja:

- az átalakulás folyamatosságát, azaz a ma müködő rendszerek elönyeire épít,

- a tárcák szakmapolitikai elgondolásainak érvényesítését,

- a térségi fejlesztések, prioritások érvényesitését,

- a visszacsatolást, az iterációt a központi, a tárcaszintủ, szektorális és a térségi tervezés között,

- a gazdaság és más fejlesztési célok nem költségvetési fejezetfüggő, egységes áttekintését. 


\section{A programkészités folyamata}

A programkészítés és -finanszírozás jelenleg érvényes fogalmi kategóriái az alábbiak:

- fejlesztés: olyan alapvetően felhalmozási kiadásokban megtestesülö tevékenység, amely új, a korábbinál müszaki, technikai szempontból korszerủbb tárgyi eszközők létrehozására irányul, illetve a meglévő tárgyi eszkőzök müszaki, technikai paramétereinek korszerüsítését valósítja meg.

- program: adott feladatok megvalósitásának folyamata, melynek finanszírozása meghatározott államháztartási források bevonásával is történik. (A későbbiekben a programok nem kizárólag állami források felhasználásával is bonyolódnak.)

A Magyarországon ma még csak bizonyos alapelemeiben alkalmazott fejlesztési programozás tág értelemben magába foglalja a tervezést és a megvalósítást egyaránt. Szưkebb értelemben egy olyan szigorú eljárási rend, amely meghatározó mind a programok kidolgozása, mind azok megvalósitása szempontjából. Még átfogóbban megfogalmazva, a klasszikus programozás ugyanis egy összetett, sokszereplős, nagyobb időtávot átfogó program decentralizált irányítási modelljét jelenti. $\mathrm{Az}$ Európai Unióban a programozás lényegéhez tartozik alapkövetelményként a finanszírozás és megvalósitás folyamatának ellenőrizhetősége, átláthatósága, ami monitoring rendszer kiépítését igényli.

A programkészítés jogszabályi elözményei és megalapozását szolgáló intézkedések az alábbiak:

1. A programozás bevezetésében már ma is vannak olyan elózmények, amelyek megfelelö ưtemezés és a fokozatosság elvének betartásával lehetöséget nyújtanak az európai elvárásoknak megfelelö programozás és programfinanszírozás bevezetésére. Elsőként kell említeni, a teruletfejlesztés jogi kereteinek meglétét, továbbá az erre alapuló további jogszabályi előzményeket.

2. A területfejlesztésröl és a területrendezésröl szóló 1996. évi XXI. tơrvény tervezési és jóváhagyási rendszert már az EU programfinanszírozási rendszerẻvel összhangban alakították ki. A programozási folyamat kialakítása jelenleg több szálon futó és némileg külön álló teruleteken fut.

3. Általánosságban közelíti a programkészités elvi és gyakorlati kiépítését néhány jogszabály.

A programkészítés folyamatának tervi feltételei: az európai típusú programozásra való áttérés

A regionális alapú fejlesztési programozási folyamat európai uniós igények szerinti teljes kiépitését a csatlakozási tárgyalások folyamán kell megvalósitani. A rendszer bevezethető már uniós tagságunk előtt is. Ez többlépcsős folyamatot jelent, amelynek eredményeként kiépül a programkészítésre alkalmas intézményrendszer és elkészull az ủn. Nemzeti Fejlesztési Terv. A Nemzeti Fejlesztési Terv kialakításának folyamatát, a hordozó intézményrendszer vonatkozásában az EU-konform támogatási rendszerröl szóló 2355/1997(XI.7) Korm. határozat szabja meg. 
Az Európai Unióban az ún. ország-programok többlépcsős iterációs folyamatban elkészülő fejlesztési célokat tartalmazó tanulmányok, ahol a programozási munka végterméke az 1. célcsoportba tartozó országok (Magyarország vélhetöen ebbe a kategóriába sorolódik) esetében a nemzeti fejlesztési program (az EU gyakorlatot, ezen belül az egyeztetési rendet az l. ábra mutatja). Az ún. „egységes programozási dokumentum" komplexen tartalmazza az összes prioritást, a hozzájuk rendelt programokat és alprogramokat, valamint az ezekhez tartozó pénzügyi, azaz finanszirozási tervet. Magyarországon ez az egyszerúbb eljárási rendủ program kialakítása valószínüsíthető.

Emellett már a csatlakozási felkészülés során szükségesnek látszik egy valamennyi fejlesztési prioritást (országos, ágazati, valamint regionális) magába foglaló országos, ún. átfogó program kidolgozása. Ez bizonyos értelemben szélesebb program, mint az EU által társ-finanszírozható Nemzeti Fejlesztési Program. Az átfogó program célja, hogy meghatározza a nemzeti sajátosságoknak megfelelö célrendszert, elválassza a nemzeti politikákat az EU társfinanszírozásba is bevonható céloktól, ezen belül pedig differenciáljon az EU különbözö alapjai által finanszírozandó célok között is.

A nemzeti és társ-finanszírozható célok kialakítását tartalmazó átfogó program alapján dolgozható ki - 2001-ben történő indítással - a Nemzeti Fejlesztési Program.

A programot az alábbiakban lehet összegezni:

- 4-6 föbb támogatási célprioritást kell megjelölni, amely levezethető a felzárkózást hátráltató regionális vagy országos problémákból.

- Valamennyi fö- és alprogramhoz biztositani kell több éven keresztül a program lefutásáig a nemzeti finanszírozást. A közösségi támogatások arányát a nemzeti (közpénzek + magảntőke) forrásokhoz viszonyítva határozza meg az EU.

- Biztosítani kell a végrehajtás minden szintre kiterjedô monitoringját, létre kell hozni egy központi monitoring egységet, valamint a minisztériumoknál és az országos hatáskörü szerveknél a Monitoring Bizottságokat.

$\mathrm{Az}$ átfogó program, valamint a Nemzeti Fejlesztési Program adta keretbe, ehhez illeszkedve készülnek a régió programok. A fenti kormányhatározat egyúttal megszabja a támogatási rendszer regionális szintjeinek a vizsgálatát, valamint a regionális tervkészités rendjének kidolgozását.

A Nemzeti Fejlesztési Program nagyságrendje, a megmozgatott források volumene miatt Parlament általi elfogadást igényel. Kidolgozása is "felülröl indított", központi koordinációt igényel. A benne lefektetett támogatási cél és prioritás-sor éves aktualizálása és a végrehajtására évente kiadott kormány és tárcarendeletek útján történhet. Ezek minden programkészitỏ számára alapinformációk. Központ szinten ("felülröl") készülnek a tárcák fejlesztési programjainak tervezetei, mégpedig regionális bontásban. Régió szinten ezen esetben az Országos Területfejlesztési Koncepció által nevesített és az Országgyủlés által elfogadott ún. statisztikai-tervezési szintek értendők. 


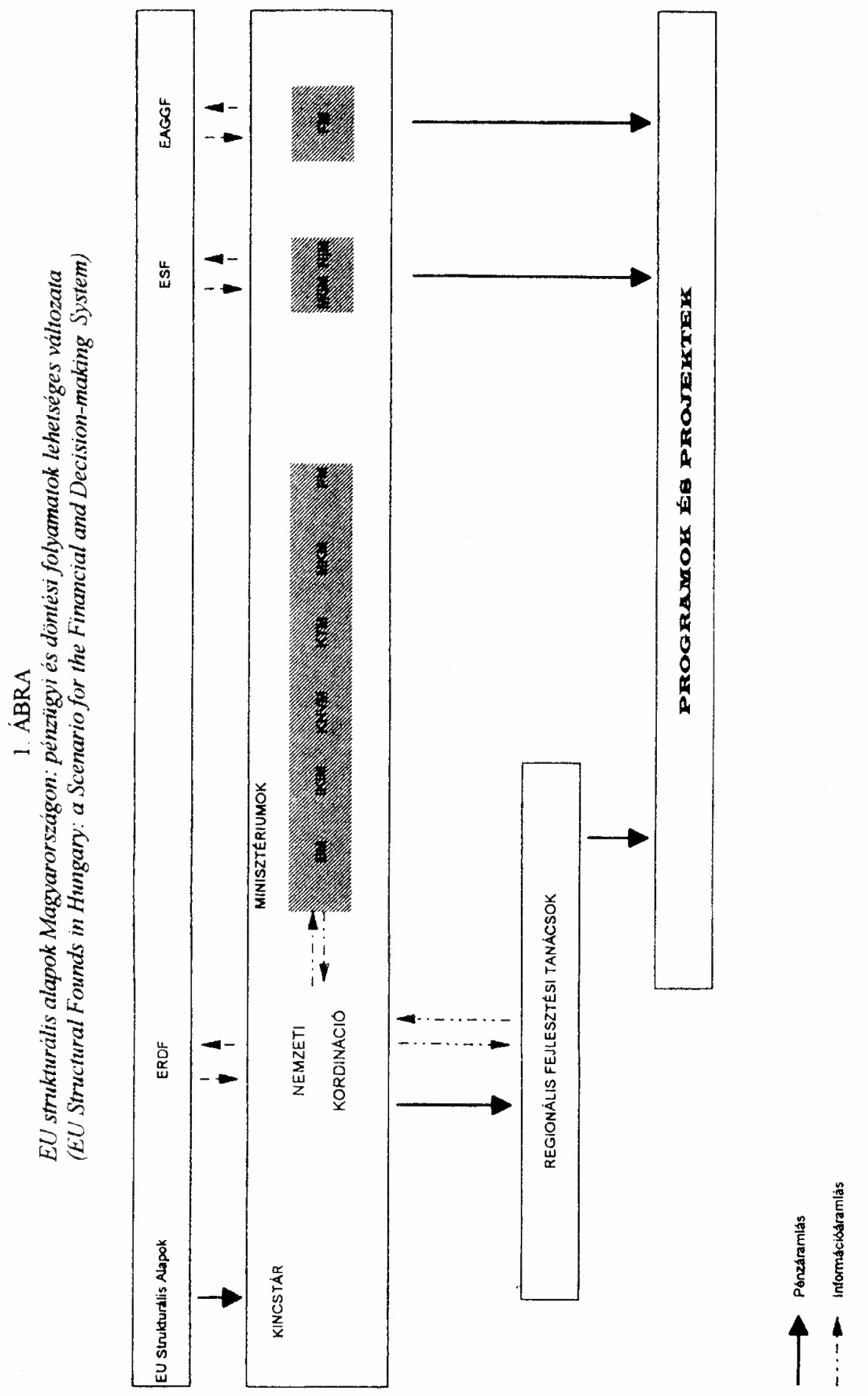


Régiók szintjén történik a tárcaprogramoknak és a megyei fejlesztési programoknak az egybehangolása. Itt történik azon területfejlesztési célok kialakítása, amelyhez a késöbbiekben EU támogatást kívánunk szerezni. A régióprogram a csatlakozás függvényében Uniós egyeztetést is igényel. A régiók fejlesztési programjának készitése a területfejlesztési tervkészités oldaláról az alábbi folyamat alapján javasolható.

A Nemzeti Fejlesztési Programmal való „összenövést” az 1996. évi XXI. sz. Területfejlesztési és rendezési törvény alapján felvázolható tervkészitési folyamat képezi. A tervezési koncepciók és programok kidolgozása mind alulról, mind felülröl építkezve megindult.

A fenti törvény két tervtípust különböztet meg: a területfejlesztési koncepciót és a területfejlesztési programot. Alapvető különbség a törvény által meghatározott tervfajták és az Európai Uniós programkészítés között, hogy egyik sem tartalmazza a koncepciók, illetve tervek megvalósítását, realizálását szolgáló pénzügyi elkötelezettségeket, csupán egyfajta koherens elgondolást összegeznek. Az uniós programkészítés elvi logikáját követve azonban ezek a koncepciók és tervek alapul szolgálhatnak a későbbi, teljes mértékben harmonizált programkészitésnek.

- A területfejlesztési koncepció az ország, illetve egy térség átfogó távlati fejlesztését megalapozó és befolyásoló tervdokumentum, ami meghatározza a térség hosszú távú, átfogó fejlesztési céljait, továbbá a fejlesztési programok kidolgozásához szükséges irányelveket, információkat biztosít az ágazati és a kapcsolódó területi tervezés és a területfejlesztés szereplöi számára.

- A területfejlesztési program a területfejlesztési koncepció alapján kidolgozott középtávú cselekvési terv, amely stratégiai és operatív programokra épül.

A stratégiai program az adott térség erös és gyenge pontjai elemzésével (SWOT-analizis), továbbá a fejlesztési koncepcióban meghatározott célok és prioritások, az igények és adottságok, az elöre jelezhető fejlődési tendenciák és az elérendő jövőkép alapján:

- meghatározza a végrehajtandó rövid- és közép távú feladatokat,

- a fejlesztéshez szưksséges lehetséges forrásokat,

- a programban közremüködök körét,

- a program eredményességének kritériumait, mutatóit,

- az együttmüködés rendszerét,

- a program egészének végrehajtásáért felelős operatív szervezetet.

Az operativ program a stratégia alapján meghatározza:

- a feladatok végrehajtásának intézkedési és ütemezési tervét,

- a részfeladatok végrehajtásáért felelös szervezeteket és közremüködőket,

- a finanszírozás módját,

- a végrehajtás mechanizmusát,

- a végrehajtás ellenőrzési rendszerét,

- az eredményesség vizsgálatának, értékelésének szempontjait. 
Lényeges eleme a folyamatnak a monitoring rendszer, ami:

- figyeli a megvalósulást,

- ellenörzi a hatékonyságot,

- jelzi a területi folyamatok által igényelt pályakorrekciót.

A fenti terv fajták definiálása lényegében már megfelel az EU irányelveinek, ahol a stratégiai programozás gerince a stratégiai tervezés, amelyhez a magyar gyakorlatban a fejlesztési koncepció készítése áll közel. A megfelelő metodikával készüllỏ kủlönböző területegységekre készült, illetve készülö fejlesztési koncepciók kib̋̋vithetők, átalakíthatók stratégiai programmá. Az átalakíthatóság egyik záloga, hogy a rövidısen kiadásra kerülő KTM-rendelet már a tartalmi követelmények kialakitásánál figyelembe veszi ezt a szempontot is (EU-konform tartalmi követelmények).

$\mathrm{Az}$ átalakitás további biztosítéka, hogy a magyar területi szerkezet jól megfeleltethetó az EU-struktúráknak, továbbá a források egy jelentős részét már ma is decentralizálták, és pályázati úton használják fel. Kialakult a pénzintézeti rendszer (kincstár, bankok), amely alkalmas a támogatások kezelésére, s folyamatban van az államháztartási rendszer átalakitása, amely alkalmas lesz a programok pénzügyi lebonyolítására és a monitoringjára.

A regionális alapú programozási folyamat a gyakorlatban különbözó - szektorális, horizontális és regionális - támogatási formákat, valamint egyes ágazati, illetve a hosszú távú területfejlesztési koncepción alapuló regionális fejlesztési terveket integrálja rendszerbe, támaszkodva a lokális, regionális szintü - partnerségen alapuló - szereplők közötti korporatív struktúrákra, a helyi köz- és magánforrások bevonására és a határ menti együttmüködés kiaknázására.

A Nemzeti Fejlesztési Program valamennyi központi fejlesztési forrás egységes tartalmi és területi áttekintését biztosítja. Ehhez kapcsolódva, erre alapozva a regionális programkészítés folyamata a hazai körülmények és a törvényi keretek figyelembevételével a következỏ séma szerint képzelhetö el. A nemzeti fejlesztési program egyszerủ, kereszttábla formájában való kidolgozását javasoljuk. A táblázat sorai a fö nemzetgazdasági fejlesztési (az EU által is támogatott) célokat, azon belül pedig a szektorális, szakmapolitikai célkitüzéseket tartalmazzák. Az oszlopok egyes térségekre lebontva tartalmazzák az 1 . célkitüzés szerinti célelöirányzatokat, ésszerúen, tervezési-statisztikai nagyrégiónként (NUTS II.), ahogyan az EU strukturális eszközeit meghatározzák.

A regionális alapú programtervezés inputjai:

- makrogazdasági követelmények, országos struktúrapolitikai prioritások,

- ágazati szakmapolitikai koncepciók,

- regionális fejlesztési programok.

Az ágazati és a regionális inputrendszer iteratív illesztése jelenti a forráskoordinációt, illesztésük feltétele, hogy:

- a térségek, mint fejlesztési célterületek az ágazati célokkal összhangban alakítsák ki prioritásaikat,

- a tárcák pedig a szakmapolitikai koncepció alapján készítsenek előzetes térségi javaslatot a források felhasználására. 
A területi bontás ez esetben nem jelent minden esetben decentralizálást is, mert a központilag finanszírozott céloknál a területi bontás indikatív jellegủ. A lebontási arányok ezekben az esetekben a területi preferenciákat csak jelzik. Ezeket a preferenciákat az elöértékelés szabályozása során lehet érvényesíteni.

A két inputrendszer iterativ illesztése jelenti a forráskoordinációt, illesztésük feltétele:

- a térségek a fejlesztési célterületek, ágazati céloknak megfelelóen alakítsák ki prioritásaikat,

- az ágazatok pedig a szakmapolitikai koncepció alapján készítsenek elözetes térségi javaslatot a források felhasználására.

A táblázat harmadik dimenzióját, a felelösségi kört külön határozzák meg. A felülröl folyó tervezési munkálatokkal párhuzamosan megindulhatnak a kistérségi stratégiai fejlesztési programok. Itt az a cél, hogy a településfejlesztési programok, vagy legalábbis azok a program-elemek, amelyekre a települések központi támogatást kívánnak igénybe venni, olyan feltétel mellett kaphassák ezt meg, hogy illeszkedniük kell az érintett kistérség fejlesztési programjába. Megyei város esetében a megyei fejlesztési programba, a föváros esetében pedig a központi régió fejlesztési programjába. A kistérségi programokat a megyei programmal folyamatosan egyeztetni kell, végül is a megyei stratégiai fejlesztési program a kistérségi programok vonatkozó elemeinek a beépítésével készül.

\section{A Nemzeti Fejlesztési Program készitésének regionális tervi feltételei}

1997. júniusban a kormány beterjesztette az országgyülés elé az Országos Területfejlesztési Koncepciót. Ennek jóváhagyását követöen a területfejlesztési koncepciók, programok tartalmi követelményeiröl szóló KTM miniszteri rendelet értelmében és annak megfelelően a megyei területfejlesztési tanácsok véglegesíthetik és jóváhagyhatják a hosszú távú megyei területfejlesztési koncepciókat. E koncepciók készítése valamennyi megyében megkezdỏdött, 1998 közepére - a csatlakozási tárgyalások ütemezésének, elörehaladtának ismeretében megtörténhet a jóváhagyásuk is. A megyei programok elfogadása után kerülhet sor a régió programok elkészitésére. A régiók fejlesztési stratégiai céljainak meghatározása után a regionális fejlesztési tanácsok keretében kerülhet sor. A régiók stratégiai programjai 1998. IV. negyedév végére elkészíthetők, és a jövő év végén való elfogadásukra is van lehetöség.

Miután a csatlakozás várható időpontja és az akkor érvényes programozási rend ismeretének hiảnya bizonytalansági tényező, így a közeljövőben életbe lépö szabályozás keretjellege megfelel az elócsatlakozási idöszakban felvállalható célnak. Kellő érdekeltség van az eljárás betartásához, ezért nem inđokolt a rendeletek módosítása. Az EU-eszköztár várható változása miatt elégséges tervezési irányelvek kialakítása.

A megyei és programozási régió szintü koncepciók ebben a formájukban még nem tartalmaznak a programok finanszírozására, pénzügyi lebonyolítására vonatkozóan a költségvetés tervezési rendszeréhez illeszkedö elgondolásokat, mivel az államháztartási rendszer és a költségvetési tervezés felkészitése erre a feladatra párhuzamosan, több lépcsőben folyik. Viszont az elvi alap azonossága a 
későbbiekre nézve alkalmas keretet biztosít, hogy a nemzeti és bevonásra kerülő külföldi források körvonalainak ismeretében, így az első ország-program összeállítása 1999-ben elvégezhetỏ a 2000-2006. közötti évekre.

A Nemzeti Fejlesztés Tervbe való átnövéséhez az eljárási javaslat egyeztetése és elfogadása után, figyelembe véve az EU-struktúra politikai eszközeit, illetve azok akkor már részletesen rendelkezésre álló tervezett átalakitását is, ha szükséges, módosítani kell a területfejlesztési koncepciók, programok tartalmi követelményeiröl szóló KTM miniszteri rendeletet, illetve a területfejlesztési koncepciók, programok és a területrendezési tervek egyeztetésének és elfogadásának rendjéről szóló kormányrendeletet.

\section{A programozás államháztartási rendszerbe való beágyazása}

\section{A magyar támogatáspolitika célrendszere és annak átalakítása}

A magyar támogatáspolitika célrendszerének kimunkálásában a célrendszer átalakításának vezérlő elve természetesen az EU támogatás-politikába való beilleszthetőség, azonban emellett $a z$ is alapvetően fontos, hogy a nemzeti kezdeményezésü fejlesztési programok a közösségi céloktól eltérő célhierarchiát és súlypontokat is hordozhatnak.

Az EU támogatási rendszeréhez való kapcsolódás keretei adottak, részben megfelelö magyar jogszabályokban lefektetettek, részben pedig a jogszabályokban megjelenỏ elvekben tükröződnek, azokból következnek, s ily módón látszólag viszonylag egyszerüen eldönthető a harmonizáció kérdése.

A támogatások EU-konformitásának alapvetỏen két aspektusa van:

- hogyan viszonyul az adott támogatás az Európai Unió versenyszabályaihoz,

- társfinanszírozásba bevonható-e a támogatás.

Egy támogatás akkor társfinanszírozható az Unióban, ha az a versenyszabályokkal nem ellentétes és beilleszthető az EU gazdasági és szociális kohéziót szolgáló célkitüzéseinek egyikébe.

Ezért az állami támogatási rendszer reformja során valamennyi változtatás és új elem bevezetése elött azokat olyan vizsgálatnak kell alávetni, amely meghatározza, hogy az EU versenyszabályaival összeegyeztethetó-e. Az ilyen irányú megítélésnek és egyeztetésnek már létezik intézményes rendje.

$\mathrm{Az}$ EU támogatási rendszerével kapcsolatban a másik követelmény a keretjelleggel lefektetett elvekből adódik: ez pedig mindenekelött a mainál jóval decentralizáltabb, számos vonatkozásban regionális elvek szerint szervezödö támogatáspolitika kialakítását jelenti.

A célrendszer kialakitásánál néhảny alapvetỏ szempont kijelölhető:

- A támogatáspolitika EU-konform átalakítảsa nemcsak a harmonizált célok átvételét feltételezi, hanem azok koherens gazdaságpolitikai megjelenítését, a támogatási rendszer makro- és mikro-szabályozási elemeinek következetes elválasztását, valamint a prioritások számszerüsíthetőségét és végrehajtásuk kiértékelhetöségét is.

- A gazdaságpolitikai elöfeltételekböl adódik, hogy a nemzeti célok meghatározásánál - tekintettel az ország abszorpciós képességére, valamint a nemzeti források szükösségére, célszerủ figyelembe venni, hogy nemzeti 
sajátosságként kell kezelni, hogy az EU-konform támogatási rendszer nem fogja azt jelenti, hogy az állami promóció csak a területi elvủ szempontokat érvényesíti. Magyarország esetében a modernizáció, a gazdasági szerkezetátalakítás kővetelménye a horizontális - minden alany számára hozzáférhetỏ támogatásokat is elótérbe állítja még a várható csatlakozás idópontjában is.

- Az elöbbiek következménye, hogy a támogatási rendszerben továbbra is indokolt fenntartani olyan szektorális intézmény- és eszközrendszert, amelynél nem a regionális preferenciákat állítjuk elötérbe (pl. a beszállitói háttéripar fejlesztésének támogatása, stb.).

- A célrendszer kialakításánál - nem utolsósorban arra tekintettel, hogy az ország egésze lényegesen az uniós átlag alatt marad, érvényesíteni kell, hogy a regionális támogatások fokozott mértékben érintsék a városi (benne nagyvárosi) térségeket is. Maga az uniós támogatási politika is ilyen irányba mozog. A nagyvárosi fejlesztési célok (metró-hálózat, stb.) bevonása nélkül nehéz lenne olyan támogatási célokat kijelölni, amelyek az ország valós igényeit fejezik ki, és érdemesek a tărs-finanszírozásra. A területfejlesztés szereplöiben is tudatositani kell, hogy az európai regionális politika nem egyenlő a vidékfejlesztés viszonylag szük horizontú célkitüzéseivel. Ez nyilvánvaló ưtközést is jelent az egysíkú válságkezelö és vidékfejlesztési orientáciojú területfejlesztési szemlélettel.

- Magán a nemzeti területfejlesztési politikán belül is bizonyos szemléletváltásra és hangsúly-eltolódásra kell számítani. Az európai regionális politikához való illeszkedés a magyar esetben - természetesen kiegyenlítési célokat is tartalmazó - "ország-fejlesztést" jelent, az ettöl elkulőnulten megjelenő nemzeti regionális politika célkeresztjében jelenhet meg (ha marad rá eszkőz) az erőteljes kiegyenlítési igény. Elképzelhető olyan terulletfejlesztési alternativa is, amely során a relatíve fejlettebb teruletek jutnak nagyobb forrásokhoz.

- A területfejlesztési politikán belüli szemléletváltáshoz tartozik, hogy céljaiban és területileg más allokációkat kell preferálnia. Az Európai Unió valamennyi támogatott térségében lényegesen nagyobb a munkahelyteremtö, vállalkozástámogató, valamint a humán infrastruktúra-beruházások aránya és kisebb a müszaki infrastruktúráé, mint Magyarországon. Az eltérés egy részét infrastruktúránk elmaradottságával lehet magyarázni, egészét azonban nem.

- A gazdaságfejlesztés súlyának nővekedéséból következik, hogy a koncentrált munkahelyteremtés szempontjából kedvezőbb feltételeket nyújtó térségi centrumok felértékelödnek.

- A nemzeti politika sajátosságát fogják alkotni azon célok, amelyek tartalmazzák, pl. az EU által nem tiltott, de a társ-finanszírozásba elvileg nem bevonható, nemzeti érdekböl azonban elengedhetetlenül szükséges, horizontális (pl. $\mathrm{K}+\mathrm{F}$, kis- és középvállalkozások elaprózódó, kis volumenü támogatása, stb.), vagy szektorális célt szolgáló (egyedi kormányzati határozatokon alapuló) támogatásokat, továbbá a társ-finanszírozható célok EU-elveknek nem megfeleló formában tơrténó támogatását is (adókedvezmények, garanciavállalás, stb.). Ide tartozhatnak speciális területpolitikai célok is. 
- A nemzeti célok kialakításánál számolni kell, hogy a megvalósuló fejlesztéseknek müködtetési, fenntartási költség vonzata is van, amelyek viszont már egyértelmủen átháríthatatlanok (tekintettel a költségvetési hiány limitjeire), s a magyar nemzetgazdaságot, elsősorban a kỏzösségi kiadásokat terhelik.

- A támogatási rendszer racionalizálásához és az EU-konform támogatáspolitika kialakításához vezető munkaprogram több évre szóló lépéssorozatot, a feladatok súlyponti és idöbeni ưtemezését feltételezi. Mindenekelött arra kell figyelemmel lenni, hogy a korszerü struktúrapolitika nemcsak a célok, a prioritások meghatározását, hanem ezek rendszerszerú mủkődését és a megvalósítási folyamat menedzselését, valamint ellenőrzését is magába foglalja. Alapelv, hogy a támogatáspolitika jövőbeni rendszere kiküszöbölje a jelenleg mükődő támogatási formák hiányosságait. Ez olyan kormányzati feladat, amelyet az EU-csatlakozástól fuggetlenul is meg kell oldani. Ezzel párhuzamosan szükséges az EU-nak a strukturális és kohéziós támogatáshoz elöirt - makrogazdasági-költségvetéspolitikai, dőntési és intézményi feltételeket érintő - követelményeihez igazodni.

- Indokolt az állami alapok és célelöirányzatok olyan átrendezése, amely lehetővé teszi a kơzfeladatok finanszírozásának és a fejlesztés támogatási rendszerének szétválasztását (müködési vagy egyértelmüen szociális finanszírozás pl. ne történjen fejlesztési célú alapokból és célelöirányzatokból). Lényeges továbbá az indokolatlan párhuzamosságok kiszủrése, a támogatások halmozódásánál a szabályozott limitek megtartása, ellenőrzése, szulkség esetén szankcionálása. A rendelet hatálya az összes alapra és fejezeti kezelésủ elöirányzatra kiterjed, s célzottan a fejlesztéspolitikát közvetlenul érintő (gazdasági szerkezet átalakítása, munkahelyteremtés, infrastruktúrafejlesztés, foglalkoztatás, $\mathrm{K}+\mathrm{F}$, felhalmozás, stb.) elóirányzatokra vonatkozóan további szabályozási szempontokat érvényesit. Ezen teruletek nagyobb léptékü projektjeire javasolható, hogy épüljön be a rendszerbe a korszerủ költség-haszon elemzés is. Minthogy a szabályozás eleve keretjellegŭ, javasoljuk, hogy a legfontosabb alapelvei érvényesüljenek az államháztartáson kívúli (pl. alapítvány) forrásokból a kis- és középvállalkozásokat támogató konstrukciók esetében is.

- A különböző alapok, céleióirányzatok racionális müködtetését szolgálóan fontos vizsgálati szempontok vetỏdnek fel a források célzottabbá, hatékonyabbá, eljárásrendjében átláthatóbbá tétele érdekében. Itt szóba jơhet szükség esetén az egyes blokkosítható források összevonása, illetve átstrukturálása (felmerülhet például a turisztikai célelỏirányzat gazdaságfejlesztési célelőirányzatba tơrténő integrálása, vagy a humán erơforrások fejlesztése érdekében az alap- és alkalmazott kutatások finanszírozását biztositó fejezeti kezelésủ költségvetési előirányzatok, célelöirányzatok ơsszevonása). 


\section{A programozás államháztartási rendszerbe való beágyazása}

$\mathrm{Az}$ EU típusú programokban a programok finanszírozására vonatkozó elgondolásokat a programkészités folyamatában definiálják. Ez azt jelenti, hogy a nemzeti költségvetés is a stratégiai programokban, a Nemzeti Fejlesztési Tervben programfinanszírozás keretében határozza meg a strukturális támogatási célokat, az állami hozzájárulás nagyságrendjét, az önkormányzatok, a gazdasági szféra számitásba veendö forrásait. Mindezek során rögzítik fejlesztési, ezen belül a területfejlesztési, valamint a külföldi forrásokból e célra biztosítható összegek közelítỏ nagyságát. Ezzel egyúttal számba veszik a fejlesztésbe bevonható egyéb (lakossági, vállalkozói) forrásokat is.

A megbízható elözetes költségtervezés kialakításához kiindulási kereteként az államháztartás információs rendszerének megújítása szükséges. A kincstár információs rendszerének célszerủ továbbfejlesztése már a programfinanszírozás jelenlegi kormányrendeletekben kialakított végrehajtásához szükséges informatikai igények alapján is megindul. Még inkább érvényesiteni kell a programozás által támasztott igényeket a kincstári rendszer továbbfejlesztése keretében. Indokolt, hogy kezelhetöbb és differenciáltabb, a gazdasági, pénzügyi események befogadására alkalmas informatikai eszközökkel váltsák föl a jelenlegi rendszert, hogy az uniós elvárásoknak megfelelően közelíthetó legyen a tervezés, a könyvvezetés és a beszámolás információs egységesítése. Erre - a decentralizált irányítási rendszernek megfelelően - mind a programgazda szervezet, mind a kincstári informatika könnyebben ráépülhet, azaz összeköthetövé válik a felsö- és alsószintủ tervezés. Ez a jelenlegi funkciókat kibóviti és egyúttal a szakmai kontrollt biztosítja. Szükségesnek tünik például, hogy a jelenlegi kincstári alapfunkció kiegészüljön a programozás pénzügyi integrátori feladataival, a beruházási jellegü projektek pénzügyi lebonyolításával, a halmozódások figyelemmel kísérésével, a projektek, programok hasznosulásának értékelésével, azaz egy pénzintézeti, fejlesztési bankszerü funkcióval.

A támogatási rendszer átalakításánál az államháztartás információs rendszerének megújításával is számolni kell. Az európai típusú programfinanszírozásra való áttérés követelményeket támaszt az államháztartási információs rendszerrel kapcsolatban olyan vonatkozásban például, hogy a támogatási nyilvántartásokat az európai nemzetgazdasági elszámolások szerint (ún. GFS rendszerben) kell vezetni.

Az EU-támogatásokhoz való hozzájutás a központi és az önkormányzati költségvetés szerkezetében változtatást igényel. Felmerülhet, hogy kủlön müködési és külön fejlesztési költségvetés készüljön.

A programfinanszírozás egyik alapfeltétele a teljes támogatási rendszer általános szabályozási keretfeltételeinek megteremtése. A rendeletben rögzitett felhasználási szabályozási alapelveket figyelembe kell venni az egyes elöirányzatokra vonatkozó végrehajtási rendelkezésekben, illetőleg a tárcaszintü szabályozásnál, hogy az alapok és a fejezeti kezelésü elöirányzatok szabályai általános követelményrendszerré álljanak össze. 
Ily módon rendszerszerủen definiálható a pályázatok útján elnyerhető támogatások általános feltételrendszere, eljárási-, finanszírozási-, ellenörzési és információs rendje, az egyes miniszterek egyeztetési és tájékoztatási feladatait tekintve.

A program - (projekt) finanszírozás irányában tett elsỏ jelentős lépés, hogy 1997-től hatályos kormányrendelet szabályozza a kincstár információs bázisán az egyes fejezeti kezelésủ előirányzatok fejlesztési költségvetését.

Mindazonáltal az eddigi mükődés tapasztalataiból már most látható, hogy a kincstár - egyoldalúan tranzakciós kódokra épülö - információs rendszere képtelen megfelelni a kormányrendelet végrehajtásához szükséges informatikai igényeknek. A kincstári rendszer átfogó továbbfejlesztése keretében ezért indokolt, hogy a tranzakciós kódokat megbízhatóbb, kezelhetőbb és differenciáltabb, a gazdasági, pénzügyi események befogadására alkalmas eszközökkel váltsuk fôl. Így megvalósulhat a tervezés, a könyvvezetés és a beszámolás információs egységesítése, amire - a decentralizált irányitási rendszernek megfelelően - mind a programgazda szervezet, mind a kincstári informatika könnyebben ráépülhet, azaz összeköthetõvé válik a felsố- és alsószintú tervezés. Ez a jelenlegi funkciókat kibővíti és a szakmai kontrollt biztosítja.

Ezzel összefüggésben azonban koncepcionális meggondolást érdemel az a kérdés, hogy a jelenlegi kincstári alapfunkció mennyiben és miként egészíthetỏ ki a programozás pénzügyi integrátori feladataival, a beruházási jellegủ projektek pénzügyi lebonyolításával, a halmozódások figyelemmel kísérésével, a projektek, programok hasznosulásának értékelésével, azaz egy pénzintézeti, fejlesztési bankszerü funkcióval.

- Hosszú távon arra kell törekedni, hogy a fejlesztési források az elsődleges célok szerint differenciálódva elkülönült pénzügyi alapokban jelenjenek meg. Ez az alapok és célelőirányzatok összevonását és átstrukturálását is jelenti.

- A támogatások tényleges folyósítása általában igen lassủ és bürokratikus, ezért tisztázni szükséges, hogyan, milyen csatornákon történhet a pénzek megelölegezése. (ez a probléma már a PHARE forrásoknál is felmerülhet) Erre, valamint a pénzkezelésre - a versenyeztetés követelményeinek eleget téve - alkalmas lehetne egy bank vagy a kincstár is. Önmagában ez a momentum is erősítheti a pénzintézeti szféra decentralizációját és/vagy a kincstár területi hálózatát.

Természetesen a projektfinanszirozást meg kell különböztetni a regionális alapú program-finanszírozástól. A program költségvetési alapokmány tartalmi leírást ad az egyes programok (feladat, projekt) azonosításáról, ideértve a program érvényességének, fejezeti hovatartozásának államháztartási egyedi azonosító meghatározását is. Ez a dokumentum pontos megnevezéssel, részletes leírással, a célállapot kijelölésével, a programot meghatározó jogszabály, pályázat, egyéb dokumentum hivatkozásával, a programmal kapcsolatos statisztikai és más mutatók megjelenítésével értelmezi a program rendeltetését. 
E szabályozási keret mind alapelveiben, mind a végrehajtás részleteiben, pénzügytechnikai eszközeiben, még ha csak egyedi fejezetekhez rendelt (projekt) objektumokra vonatkozóan is, de fó struktúráját tekintve is megfelel a program finanszírozás nemzetközileg elterjedt rendszerének.

Ugyanakkor az eddig megtett lépéseken túl további finomításra szorul a magyar költségvetés EU-igényeket kielégító átalakitásán belül a fejlesztési költségek tervezése, valamint a fejlesztésekhez kapcsolódó, hosszú távú elkötelezettségek kialakítása is. Ennek egyik eszköze lehet, hogy a finanszírozási rendszerbe olyan automatizmusokat kell beépíteni, amelyek lehetővé teszik a több évre tervezést, és csak igen szulk sávban engedélyeznek mozgásokat, eltéréseket annak érdekében, hogy a kötelezö vállalásoknak a pénziigyi tervben foglalt ütemezésben és módon az önkormányzatok eleget tudjanak tenni.

A program-finanszírozás egyik legfontosabb alapfeltétele a teljes támogatási rendszer általános szabályozási keretfeltételeinek megteremtése. Az ehhez vezető egyik kiemelkedően fontos lépcsó az a kormányrendelet, amelyet a közeljövőben hoznak nyilvánosságra, és amely hatékony lépés az EU típusú programfinanszírozás irányába is.

A rendelet rögzíti a felhasználási szabályozási alapelveket, amelyeket figyelembe kell venni az egyes elóirányzatokra vonatkozó végrehajtási rendelkezésekben, illetőleg a tárcaszintủ szabályozásnál, hogy az alapok és a fejezeti kezelésú elóirányzatok szabályai általános követelményrendszerben álljanak össze. Ily módon rendszerszerủen definiálható a pályázatok útjản elnyerhetỏ támogatások általános feltételrendszere, eljárási-, finanszírozási-, ellenörzési és információs rendje, az egyes miniszterek egyeztetési és tájékoztatási feladatait tekintve.

\section{A finanszirozás területi decentralizációja}

A programozási alapelv érvényesítése sokkal bonyolultabb feladat annál, mintsem hogy a monitoring és pénzügyi ellenörzés problémáját csupán a kincstár informatikai rendszerfejlesztése szempontjából gondoljuk végig. A klasszikus programozás ugyanis egy összetett, sokszereplös, nagyobb időtávot átfogó program decentralizált irányitási modelljét jelenti.

Ezen belul kulön speciális problémát jelent, pl. a területileg decentralizált finanszirozási rendszer - központi, fejezeti, illetve a megyei fejlesztési tanácsok hatáskörébe utalt feladatai végrehajtásának összehangolása is. Mindez egyrészt felveti:

- a decentralizált támogatási rendszer törvényi kereteinek és a végrehajtási jogszabályok konzisztenciájának érvényesítését, kủlönös tekintettel a finanszírozási modell - EU-konform - megvalósítását tekintve;

- másrészt gondoskodni kell e szabályrendszer pénzügyi lebonyolitásának elsósorban a kincstárt érintő - intézményi feltételeiröl, ideértve a társfinanszírozásban résztvevő további szereplök (megyei fejlesztési tanácsok, helyi önkormányzatok, stb.) feladatait, kötelezettségeit is. 
Más típusú, átfogóbb megközelítést jelent, hogy a decentralizált döntési elvnek megfelelöen a helyi önkormányzatok finanszírozását egyszerübbé és áttekinthetőbbé tevő forrásszabályozásban a helyhatóságok jövedelem-részesedését növelni szükséges, ugyanakkor kiegyenlítő mechanizmusokat kell érvényesíteni.

A finanszírozási rendszer hatékonyságát fokozhatja a központi kormányzat, a régió és a területfejlesztés többi szereplője között létrejövő tervszerződések mechanizmusa, a különbözỏ források egyesítésének és felhasználásának jogipénzügyi kötelezettségeit tartalmazó dokumentum.

A költségvetés a stratégiai programokban, a Nemzeti Fejlesztési Tervben program finanszírozás keretében határozza meg a strukturális támogatási célokat, az állami hozzájárulás nagyságrendjét, az önkormányzatok, a gazdasági szféra számításba veendő forrásait. Mindezek során rögzítendỏ a területfejlesztési, valamint a külföldi forrásokból e célra biztosítható összegek nagyságrendje. A lakossági források bevonására, a befektetök megnyerésére jelentős szemléletváltást is eredményező külön program dolgozandó ki.

Az önkormányzati finanszírozást olyan irányban kell fejleszteni, hogy minden önkormányzat részére elegendő forrás jusson a kötelező feladatok ellátására, s lehetővé váljon a forrásképzés az önként vállalt feladatok, a pótlás és a fejlesztések megvalósitására, a területfejlesztési célokhoz való hozzájárulásra. Ez a rendszer eredményezheti, hogy mind az önkormányzatok, mind a különböző területfejlesztési szereplők részt tudjanak venni a fejlesztések finanszírozásában. Ennek másik oldala, hogy az onkormányzati helyi fejlesztések finanszírozása alapvetỏen az önkormányzati és a helyi gazdasági forrásokból történjen. Alanyi jogon csak akkor van szükség központi támogatásra, ha egy helyi fejlesztési cél országos probléma megoldását segíti elő, beruházási költségigénye igen magas, megtérülésére csak hosszú távon van remény, és egyéb források bevonása nehézkes.

A finanszírozási rendszerbe olyan automatizmusokat kell beépíteni, amelyek lehetővé teszik a több évre tervezést, és csak igen szük sávban engedélyeznek mozgásokat, eltéréseket annak érdekében, hogy a kötelező vállalásoknak a pénzügyi tervben foglalt ütemezésben és módon az önkormányzatok eleget tudjanak tenni.

A területfejlesztés központi, regionális, megyei programjainak támogatási rendszere, valamint a pénzeszközök felhasználásának ellenőrzési rendszere

A klasszikus programozás egy összetett, sokszereplös, nagyobb időtávot átfogó program decentralizált irányítási modelljét jelenti, amelyben a területfejlesztés szereplöi a partnerség elvén keresztül kapcsolódnak egymáshoz. Ma azonban a területfejlesztés meghatározó szerepet betöltő szereplőinek igen kevés saját forrás áll rendelkezésére. Ezért a programozás hatékony és eredményes alkalmazásához végig kell gondolni a fiskális decentralizáció lehetséges útjait. A már említett Agenda 2000 dokumentum javasolja, hogy a legnagyobb figyelmet a partnerség elvének betartására kell helyezni, ehhez pedig valódi elmozdulást kell elérni a fiskális decentralizációban. 
A fiskális decentralizáció felé való elmozdulás folyamatán belül külön speciális problémát jelent, pl, a területileg decentralizált finanszírozási rendszer - központi, fejezeti, illetve a megyei fejlesztési tanácsok hatáskörébe utalt feladatai végrehajtásának összehangolása is.

A területfejlesztés központi, regionális, megyei programjainak támogatási rendszerére vonatkozó átalakítás menetét elsösorban a támogatási rendszer EU-konform átalakitásából adódó feladatok határozzák meg. A magyar támogatási rendszerünk átalakításához, a támogatási rendszer ésszerüsitéséhez és az EU-konform támogatás-politika kialakításához vezetó munkaprogram tơbb évre szóló lépéssorozatot, a feladatok súlyponti és időbeni ütemezését feltételezi. Mindenekelött azt kell tekintetbe venni, hogy a korszerü struktúrapolitika nemcsak a célok, a prioritások meghatározását, hanem ezek rendszerszerủ múködését, a megvalósitási folyamat menedzselését, valamint ellenőrzését is magába foglalja. Alapelv, hogy a támogatás-politika jövőbeni rendszere kiküszöbölje a jelenleg múködö támogatási formák hiányosságait. Ez olyan kormányzati feladat, amelyet az EU-csatlakozástól fưggetlenül is meg kell oldani. Ezzel párhuzamosan szükséges az EU-nak a strukturális és kohéziós támogatáshoz elöírt - makrogazdaságiköltségvetéspolitikai, döntési és intézményi feltételeket érintő - követelményeihez igazodni.

Becslések szerint a magyar támogatás politika elemei jelenleg mintegy 60-70\%-ban azonosíthatók az Európai Unióban alkalmazott támogatás politika céljaival és elveivel. Az állami fejlesztési támogatási rendszer elemeinek ma (több különböző szakértői becslést figyelembe véve) mintegy 60-62\%-át Budapesten kívül használják fel. Az egységes fejlesztési elvek alkalmazása érdekében a központi régiót is számításba kell venni, a regionális programozásba be kell vonni.

Az államháztartás információs rendszerének hiányosságai miatt a teljes támogatáspolitika térbeli megoszlásának vizsgálata ez idáig nem történhetett meg. Így csak kơzvetett információk és becslések révén állítható össze a kép, amely az alábbiakban jellemezhetó:

- az állami támogatás és fejlesztés-politika a kilencvenes évek folyamán nem szolgált nivellációs célokat, gyakorlatilag a fejlesztési célú közpénzek 38-40\%-át kơzponti régióban használják fel, s a fejlett régiók aránya is magasabb volt, mint az gazdasági szerepük vagy népesség-arányuk alapján indokolt lett volna;

- a hagyományos értelemben területfejlesztési (nivellációs és válságkezelö) célú eszkðzơk területi allokációja megfelelt az elvárásoknak, de nagyságrendjuknél fogva csak tüneti kezelést jelentettek.

A támogatási rendszer regionalizálásával kapcsolatban az alábbi teendök elvégzése szükséges a támogatási rendszer jelenlegi formájában az egyes elemek horizontális és regionális jellegének, annak mértékének meghatározása, a várható továbbfejlődés irányának megfelelően a regionális programokba való integrálhatóságának a megvizsgálása, továbbá a döntési kompetenciák és a finanszírozás függvényében a különbözỏ területi szintek meghatározása. 
Gyakorlati szempontból aggályosnak tartható a 19 megyei fejlesztési program racionális időkereteken belüli egyeztetési folyamatának a jelenlegi közigazgatási kapacitási keretek között, így javasolható, hogy a külön megyei programok rendszerét hagyni kell elcsökevényesedni, s kizárólag a régiók és a központi kormányzat között legyenek "programalkuk".

A régió egyeztetö fórum a központi szervek és a nagyobb autonómiást élvezö megyék között. Ezt biztosítja a régiók fejlesztési tanácsának összetétele is. A tényleges forrásallokációt a költségvetési törvény keretében az OGY végzi. A partnerség elve érvényesül a megyei területfejlesztési tanácsokban is. A 2. ábrán feltüntettünk egy lehetséges elvi sémát, amely a korszerú regionális alapú programfinanszírozás kialakításának folyamatát modellezi.

Ma az államháztartásban bevezetett program fogalom az uniós kategóriánál szükebb fogalmat takar (habár a Borsod-Abaúj-Zemplén megyei integrált szerkezetátalakitási program keretében folyik PHARE-források felhasználása is).

Jelenleg az adott feladatok megvalósításának folyamatát határozzák meg, melynek finanszírozása meghatározott államháztartási források bevonásával történik. (A későbbiekben az EU támogatási rendszeréhez való illeszkedéssel a programok nem kizárólag állami források felhasználásával bonyolódnak, hanem az uniós források mellett a hazai és külföldi magánszféra, hitel szféra, stb. is bekapcsolódik, így a programoknak az államháztartási rendszer belüli kezelése, különösen az információs rendszer oldaláról még bonyolultabbá válik.)

Meg kell állapítanunk, hogy az ez irányú lépések és tényleges elörehaladás ellenére az európai típusú programozás bevezetésének legföbb akadálya éppen a jelenlegi folyó költségvetési tervezési gyakorlat. İgy a stratégiai és operatív programokból is hiányzik a reális költségvetési háttér.

A finanszírozási rendszer hatékonyságát fokozhatja a központi kormányzat, a régió és a területfejlesztés többi szereplöje között létrejövő - a nemzetközi gyakorlatban ismert és jól múködő mechanizmusnak, a tervszerződések (a különböző források egyesítésének és felhasználásának jogi-pénzügyi kötelezettségeit tartalmazó dokumentum) rendszerének a kialakítása és múködtetése. Ennek a kidolgozása valószínúleg jól adaptálható a magyar gyakorlatba, s ezért az ezzel kapcsolatos elgondolások kialakítása sürgetö feladat. A tervszerzödés tartalmazza a célok megvalósításának szintjeit, ezek elérésének módját, a végrehajtandó fejlesztéseket, kijelöli a végrehajtásért felelös szervezetet, a végrehajtás ütemezését, a pénzügyi hozzajjárulás összegét, finanszirozási feltételeit és ưtemezését, a programteljesítésről szóló beszámoló rendjét. 


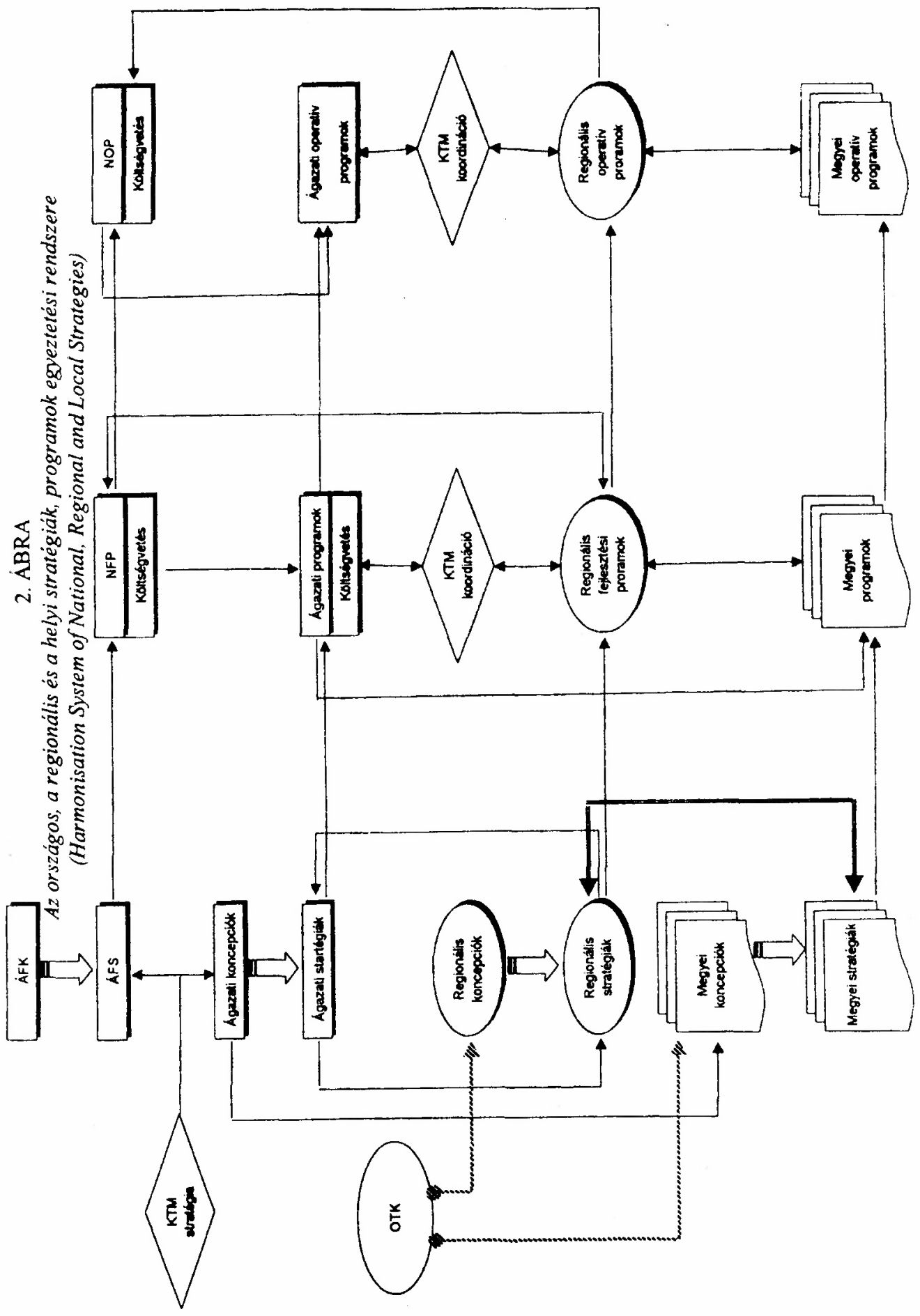


A programok monitoring rendszere

A programokkal kapcsolatos monitoring bizottságokat kell szervezni. Ezek összetételét és jogkörüket az uniós források felhasználása esetén elöirások szabályozzák. A monitoring bizottság ellenörzi:

- a programcélok kitüzésének a szakmai helyességét,

- a részarányos teljesítést,

- a program elörehaladását, befejeződését,

- a program eredményességét, a program-szerződésben rögzített célok teljesítését.

A monitoring bizottságokat alapjában véve régiónként kell szervezni. Lehetséges azonban, hogy ilyenekre megyénként is szủkség lehet, akár önállóan, akár pedig albizottság formájában. A programokhoz kidolgozásához és monitoringhoz megfelelö információs rendszer szükséges. Ennek két fö alrendszere van:

- A természeti - társadalmi - gazdasági helyzet és folyamatok regisztrálása és figyelemmel kísérése.

- A támogatásokra és a pénzügyi müködésre vonatkozó adatok számon tartása.

A területi információs rendszer megszervezéséröl az 1996. évi XXI. sz. Területfejlesztési és rendezési törvény intézkedett, kiépültek annak országos és területei (megyei) központjai, illetöleg az igényekhez mérten már régió- és kistérségi szinten is szerveződnek. A pénzügyekkel kapcsolatos információs rendszer kialakításról a már említett 2355/1997. (XI.7.) Kormányhatározat az EU-konform támogatási rendszerekről intézkedik.

A programozási folyamatban - miután több szálon és némileg külön álló területeken fut - így a különböző területeken folyó tevékenységeket össze kell hangolni, és erre intézkedési tervet kell kidolgozni.

\section{TOWARDS A NEW SYSTEM OF REGIONAL DEVELOPMENT FINANCE: ADAPTATION TO THE EU STANDARDS}

\section{ÉVA RUTTKAY}

National financial system of regional development finance system should be modernised and adjusted to the European standards. The approaching enlargement of the European Union raised the following issues:

- Adaptation of economic policy that should be focused on the improvement of competitiveness of the economy and ease of territorial differentiation;

- Enhancement of absorptive capacities including human, institutional and economic (financial) factors to obtain resources from EU funds;

- A new, decentralised model of financial framework should be established;

- A mid-term planning system must be formulated, including the elaboration of a national programming system that is adjusted to the EU standards and fitted into the national economic policy. 
To realise strategic purposes outlined above, institutions of territorial administration must be made operational furthermore, functions of central governmental and regional authorities should be clarified. The main constraint of the introduction of a new programming system is the recent financial policy that provide insufficient resources to ease regional differences and realise long-term development strategies. To set up a working programming system, financial conditions and institutional background must be improved furthermore, the programming process must be co-ordinated and an information and monitoring system should be established. 